DOI https://doi.org/10.30525/978-9934-26-004-9-57

\title{
ІДЕАЛ ЖІНОЧОЇ ВРОДИ ДОБИ ЦІН НА ПРИКЛАДІ ТВОРІВ КИТАЙСЬКОЇ ПОРЦЕЛЯНИ
}

\author{
Новікова О. В. \\ аспірантка кафедри теорії та історії мистецтвва \\ Національної академії образотворчого мистецттва і архітектури \\ м. Київ, Украӥна
}

Краса є одним 3 найбільш суб'єктивних понять. Як відомо, ії канони ніколи не були сталими. У традиційній китайській системі цінностей питання жіночої вроди невід'ємно асоціювалось із поведінкою, манерами, вихованням. I хоча у Китаї існували певні стандарти зовнішності, вродливими вважали насамперед розумних жінок, які красиво (тобто правильно) поводяться. Дійсно, на думку тогочасних китайців, красивою $\epsilon$ жінка, яка шанує батьків, покірна чоловікові, віддана дітям. Зокрема чиновник Лань Діньюань (1680-1733) зазначав: «Основа державної влади - народні звичаї. Звичаї народу визначаються родинним життям. Сімейне життя залежить від жіночої поведінки» [3, с. 548].

Отже, жінка цінувалась настільки, наскільки була потрібною для функціонування родини і ведення господарства. Це вповні співпадало із християнською традицією, у якій жіночим ідеалом була Діва Марія покірна, цнотлива, лагідна. А головною місією ii життя було материнство.

Щодо манер і виховання, то в обох культурах цінувалось вміння жінки відповідно поводитись. Так, гарна жінка плавно рухається, має рівну поставу, вона привітна, проте не виказує зайвих емоцій.

Згідно $з$ китайськими стандартами щодо еліти, вродлива жінка - це жінка освічена, яка практикує самовдосконалення. Китайці як ніхто цінували знання. Відомо, що тільки освічені чоловіки могли розраховувати на вдалу кар'єру. Те саме стосувалось і представників еліти. Кожен китайський «джентльмен», тобто вчений/інтелігент ши ${ }^{4} \pm$ мав опанувати сиї 四艺 - чотири уміння/заняття або цінь ці шу хва 琴棋 书画: гру на гуціні, гру в го, каліграфію та живопис [8, с. 68].

Вихована освічена китайська пані також мала ними володіти. Таких китайці ще кликали гвейсьов 閏秀, тобто «добре виховані пані». Англійська письменниця Джейн Остін (1775-1817) вустами героїні міс

4 Тут і далі використано українську практичну транскрипцію китайської мови Н. Кірносової, Н. Цісар, видану в 2020 р. [2]. 
Бінглі у книзі «Гордість та упередження» описувала досконалу леді так: «... вона має добре знатися на музиці, співах, малюванні, танцях, мовах...» [5, с. 35].

У Китаї шанобливої назви «леді», тобто гвейсьов, заслуговували тільки ті жінки, яким вдалось опанувати цінь ці шу хва.

У творах образотворчого мистецтва доби Цін особливо популярними стали зображення таких гвейсьов за повсякденними заняттями (вишивання, читання, причепурювання, заварювання чаю, споглядання саду) в оточенні різних предметів - атрибутів мистецтв (сишу), предметів давнини (гу). Такі зображення відповідали установленому ідеалу китайської пані, що стосується іiі вроди, статусу та ролі у суспільстві [8, с. 61].

Звернемо увагу на серію порцелянових тарілок часів правління імператорів Йонджена (1723-1735) та Цяньлона (1735-1795). Центральним мотив - зображення жінки, яка сидять за столом в оточенні різних предметів. Ймовірним зразком цього мотиву слугувала серія композицій Їньджен фей сінлету 胤镇妃行乐图 «Дозвілля наложниць принца Їньджена», створена у 1709-1723 роках для оздоблення особистих покоїв майбутнього імператора Йонджена [4, с. 6; 7, c. 258,431$]$.

Виконані на межі портретного та жанрового живопису, наложниці представляють зразок ідеалізованого куртуазного типу, далекого від реальності. Але художники-керамісти дещо змінили композицію і додали дитя/двійко дітей, надавши їй морально-етичного змісту. Ймовірно, образ жінки із дитям китайці запозичили у європейців унаслідок знайомства із творами християнського мистецтва, що розповсюджували місіонери.

Щодо питання відображення жіночої вроди у китайському мистецтві, то тут очевидна тотальна розбіжність із європейською традицією. Європейські художники услід за античними митцями «смакували» усі вигини і ракурси людського тіла. Китайські митці, напроти, вкрай рідко зображували оголену натуру. Виключення становили картини еротичної тематики чвеньгонту 春宫图, що виконувались як посібники для практикуючих. Крім того, у таких творах завжди фігурувала пара чоловік-жінка, як утілення ідеї взаємопроникнення їнь-ян. На відміну від численних європейських пишнотілих красунь, у китайській традиції жінку саму по собі майже ніколи не зображували оголеною [1, с. 30].

Пластичне мислення, загалом не було притаманним китайській образотворчій традиції. Саме площинний живопис, а не об'ємна скульптура, був провідним видом китайського мистецтва [1, с. 32].

Художники-керамісти услід за живописцями та графіками на творах китайської порцеляни зображували над-тілесні жіночі образи, повністю 
позбавлені індивідуальних рис. Натомість зображення красунь неможливо уявити без повного набору декоративних атрибутів: макіяжу, зачіски, прикрас, вбрання. Жіноче тіло 3 пишними формами недовго було в моді за доби Тан (618-907) завдяки одній з чотирьох красунь давнини - Ян Гвейфей (719-756), коханій імператора Сюань Дзуна (712-756). Її параметри стали взірцем для численних фігурок китайської поховальної кераміки мінці («духовні предмети»). Та поступово у Серединній імперії ствердився інший тип жіночої зовнішності. Відтоді красуня мала бути субтильною, манірною, декоративною.

Саме такі зображення жінок зі стрункими видовженими фігурами стали одними із найулюбленіших мотивів художників-керамістів часів Мін (1368-1644) та Цін (1644-1911). Особливо часто їх можна зустріти на творах синьо-білого китайського фарфору XVII століття. Голландці, які в цей час активно завозили китайський фарфор до Свропи, назвали тендітних героїнь синьо-білих розписів Lange Lijzen (Ланге Лейзен). Пізніше англійці трансформували цю назву у «Long Elizas», тобто «Довгов'язі Елізи», яка й закріпилась у європейській термінології [6, с. 219-220].

Вироби китайської порцеляни із тонкими прозорими стінками якнайкраще асоціюються із ідеалом жіночої краси, опис якої стрічаємо в книзі «Розваги та чудернацьке (Сяньцін овдзі 闲情偶寄), написаній Лі Ю (1610-1680) у 1671 р. Так, у розділі «О́брази та голоси» (шенжон бу 聲容部) автор детально описав, що робить жінку вродливою. Він відзначає, що іï погляд має бути живим та розумними («яке задоволення може викликати лише один погляд прекрасних розумних очей $«)$; чоловік при виборі коханої, зосереджується на їі маленьких, схожих на лотос стопах; він обов'язково звертає увагу на їі витончені руки [8, с. 65].

У пам'ятках образотворчого мистецтва зображення китайських красунь створені відповідно до цих ознак: із маленькими долонями та тонкими тендітними пальцями, маленькими лотосовими ніжками у розкішних черевичках. На творах китайського фарфору також спостерігаємо увічнені Лу Ю та іншими авторами стандарти жіночої вроди: білу порцелянову шкіру, брови у формі півмісяця або далеких гірських вершин, вузькі виразні очі, обличчя у формі місяця та маленькі червоні вуста у формі кружечка [8, с. 65].

Китайські поети залюбки порівнювали обличчя красуні із шляхетною яшмою, брови - із обрисами далеких гір, блиск очей - із сяйвом сонця або місяця, складну зачіску - із хмаринкою, драконом та феніксом [3, с. 544].

У творах китайської порцеляни доби Цін, регламентованій імперською владою, відобразилась придворна елітарна культура. Жіночі

\footnotetext{
${ }^{5}$ Austen J. Pride and Prejudice. - Wordsworth Classics, 2007. - c. 25. [5]
} 
образи представлені як ідеалізовані типи у відповідності до традиційних уявлень про їх соціальні ролі.

\title{
Література:
}

1. Городецкая О. М. Искусство «весеннего дворца». Китайский Эрос / под ред. А. И. Кобзева. ОСR Палек, 1998. 282 с.

2. Кірносова Н. А., Цісар Н. 3. Пекін vs Бейдзін, Чжуанцзи vs Джвандзи: проєкт української практичної транскрипції китайської мови. К.: Сафран, 2020. 128 с.

3. Малявин В. Китайская цивилизация. М.: Астрель, 2000. 531 с.

4. Неглинская М. А. Китайский стиль цинского двора (1644-1911) и европейский предмодернизм. М.: Спутник+, 2018. 432 с.

5. Austen J. Pride and Prejudice. - Wordsworth Classics, 2007. 329 p.

6. Valenstein S. A Handbook of Chinese ceramics. Revised and enlarged edition The Metropolitan Museum of art New York, 1988. $331 \mathrm{p}$.

7. Rawsky E. S., Rawson J. China. The Three Emperors 1662-1795. The Royal Academy of Arts, 2005. 358 p.

8. Wang A. X. The Idealised Lives of Women: Visions of Beauty in Chinese Popular Prints of the Qing Dynasty / Arts Asiatiques, tome 73, 2018. P. 61-80. doi : https://doi.org/10.3406/arasi.2018.1993

DOI https://doi.org/10.30525/978-9934-26-004-9-58

РЕСТАВРАЦІЯ ІКОНИ «ХРИСТОС СПАСИТЕЛЬ» ХІХ СТ. ІЗ ЗБІРКИ НАЦІОНАЛЬНОГО АРХІТЕКТУРНО-ІСТОРИЧНОГО ЗАПОВІДНИКА «ЧЕРНІГІВ СТАРОДАВНІЙ»

\author{
Петренко А. А. \\ викладач кафедри образотворчого мистечтва та дизайну \\ Центральноукраӥнського державного педагогічного університету \\ імені Володимира Винниченка \\ м. Кропивницький, Україна
}

Пам'ятка надійшла у Національну Академію образотворчого мистецтва та архітектури на кафедру техніки та реставрації творів мистецтва у 2016 році на проведення консерваційно-реставраційних заходів із фондів Національного архітектурно-історичного заповідника «Чернігів Стародавній». 